\title{
Morphology and phylogeny of three planktonic Radiococcaceae sensu lato species (Sphaeropleales, Chlorophyceae) from China, including the description of a new species Planktosphaeria hubeiensis sp. nov.
}

\author{
Qi ZHANG ${ }^{1}$, Lingling ZHENG ${ }^{1}$, Tianli $\mathrm{LI}^{2}$, Guoxiang $\mathrm{LIU}^{2} \&$ Lirong SONG ${ }^{1 *}$ \\ ${ }^{1}$ State Key Laboratory of Freshwater Ecology and Biotechnology, Institute of Hydrobiology, Chinese Academy \\ of Sciences, 430072 Wuhan, China; *Corresponding author e-mail: lrsong@ihb.ac.cn \\ ${ }^{2}$ Key Laboratory of Algal Biology, Institute of Hydrobiology, Chinese Academy of Sciences, 430072 Wuhan, China
}

\begin{abstract}
The family Radiococcaceae sensu lato, defined as colonial autospore-producing mucilaginous coccoid green algae, is widespread in terrestrial and freshwater habitats. Three species of Radiococcaceae sensu lato, including two Radiococcus species and one Planktosphaeria species, were described from China by light and electron microscopy. A new species of Planktosphaeria, Planktosphaeria hubeiensis sp. nov. was erected based on morphological comparisons and genetic analyses. Our phylogenetic analyses indicated that Radiococcaceae sensu lato is polyphyletic, and separated into three lineages. The Radiococcus species did not cluster into a monophyletic group in phylogenetic analyses; therefore the taxonomy of the genus Radiococcus should be revised in the future.
\end{abstract}

Key words: morphology, Planktosphaeria, phylogeny, Radiococcaceae, Radiococcus, taxonomy

\section{INTRODUCTION}

Coccoid green algae are found commonly in aquatic and terrestrial habitats worldwide, including extreme environments such as postmining dumps, polar arid soils, and deserts (e.g. BROADY 1986; FLECHTNER et al. 1998; РATOVA \& DorokHova 2008; FuČ́́Ková et al. 2014). Conventionally, many coccoid taxa were assigned to the order Chlorococcales sensu lato in the publication of the famous handbook on "Chlorococcales" by KомÁREK \& Fотт (1983). However, the majority of coccoid green algae are now understood as a polyphyletic assemblage of taxa distributed into Chlorophyceae, Trebouxiophyceae, and Prasinophyceae within the division Chlorophyta (KrienITZ et al. 2003; LewIS \& MCCourT 2004; KrIENITZ \& Bock 2012). They are important primary producers in freshwater communities, but very little is known about their diversity due to their extremely small size and simple morphology, which makes identification by light microscopy essentially impossible (SOYLU \& GöNüLOL 2012).

Within the chlorophycean order Sphaeropleales, several taxa are coccoid green algae in mucilaginous colonies. Many coccoid mucilaginous green algae were placed in the families Palmellaceae or Chlorellaceae in early generic system (LEMMERMANN 1915; KORSHIKOV 1953), and then transferred to the family Radiococcaceae (FoTT
1959). The Radiococcaceae was erected by FoтT (1959), validated by КомáReк (1979) and revised by KostiKov et al. (2002). The family comprised autospore-producing and zoospore-producing species in early definition (FotT 1959), then was restricted to autospore-producing species only in later revision (KoMÁREK 1979). Now the family Radiococcaceae sensu lato can be defined as colonial autospore-producing green algae with spherical, regularly or irregularly ellipsoid cells with a smooth cell wall, lacking vegetative cell division, lying in more or less thick and more or less strong mucilage (Kostikov et al. 2002). The Radiococcaceae sensu lato is distributed in freshwater as well as terrestrial habitats worldwide, and it is one of the most taxonomically difficult groups in green algae (PAžoutoví 2008). Radiococcacean systematics is not clearly delimited, and there is still much discussion about the taxonomic systems used to classify species (ALVES et al. 2014). The scope of this family has been changed according to the view of the different authors. All these considerations are based on morphological characteristics (WoLf et al. 2003). Ultrastructural data and molecular phylogenetic analyses of this family are still scarce (KostiKov et al. 2002). The phylogenetic analyses based on $18 \mathrm{~S}$ rRNA gene sequences of three strains of Radiococcus polycoccus (Korshikov) I. Kostikov, T. Darienko, A. Lukesová et L. Hoffmann, one strain of Planktosphaeria gelatinosa G.M. SмIтH 
and one strain of Schizochlamydella capsulata (West) Korshikov (Radiococcaceae, Chlorophyta) indicated that the Radiococcaceae could be a polyphyletic assemblage of coccoid mucilage forming chlorophytes (WoLF et al. 2003). Phylogenetic analyses of a multigene dataset from all sphaeroplealean families were used to examine the monophyly of these morphologically similar taxa, which were shown instead to be phylogenetically distinct and very divergent (FučíKoví et al. 2014).

In this study, we investigated four planktonic strains of Radiococcaceae sensu lato in different inland waters from China. We characterized the morphology, ultrastructure and phylogenetic position of these strains. Three strains belonged to the genus Radiococcus Schmidle, and the other one was described as a new species of Planktosphaeria G.M. Smith.

\section{Material ANd Methods}

The algal strains were isolated from three different freshwater environments in China, and deposited at the Freshwater Algae Culture Collection at the Institute of Hydrobiology (FACHB, China) (Table 1). The strains were cultivated on agar-solidified and liquid BG11 medium (STANIER et al. 1971) at $22{ }^{\circ} \mathrm{C}$ under a $12 \mathrm{~h}: 12 \mathrm{~h}$ light-dark regime, with illumination of 20 $\mu \mathrm{mol} \cdot \mathrm{m}^{-2} \cdot \mathrm{s}^{-1}$.

For morphological observations and microphotography an Olympus BX 53 light microscope (Olympus, Tokyo, Japan) with differential interference contrast were used. Micrographs were taken with an Olympus DP80 digital camera (Olympus, Tokyo, Japan) and Olympus software cellSens Standard (v. 1.14).

For transmission electron microscopy, samples of each strain were fixed for $2 \mathrm{~h}$ in $2 \%$ glutaraldehyde in $0.05 \mathrm{M}$ phosphate buffer, and postfixed for $2 \mathrm{~h}$ in $1 \%$ osmium tetroxide in $0.05 \mathrm{M}$ phosphate buffer, subsequently for $12 \mathrm{~h}$ in $1 \%$ uranyl acetate solution. Then the samples were dehydrated through an ethanol series and embedded in Spurr's medium via propylene oxide (SPURR 1969). Ultrathin sections were cut using a diamond knife on Leica UC-7 (Leica, Wetzlar, Germany) and poststained with lead citrate. Observations were carried out using a Hitachi HT-7700 transmission electron microscope (Hitachi, Tokyo, Japan).
Total genomic DNA was extracted using the Universal DNA Isolation Kit (AxyPrep, Hangzhou, China). PCR amplification was performed using $3 \mu \mathrm{L}$ template DNA, $0.4 \mu \mathrm{mol} / \mathrm{L}$ each primer, and $25 \mu \mathrm{L} 2 \times$ Taq Master Mix (ExTaq; Takara, Dalian, China) in a $50 \mu \mathrm{L}$ reaction volume. Two sets of PCR primers were used for PCR amplification of SSU rDNA (18S-F, 5'-AACCTGGTTGATCCTGCCAGT-3'; 18S-R, 5'-TGATCCTTCTGCAGGTTCACCTACG-3') (KATANA et al. 2001), and ITS region, including ITS1, 5.8S rDNA, and ITS2 (ITS-F, 5'-CAAGGTTTCCGTAGGTGA-3'; ITS-R, 5'- GGCATCCTGGTTAGTTTCT-3') (Luo et al. 2006). The SSU and ITS PCR began with 2 min at $94{ }^{\circ} \mathrm{C}$, followed by 35 cycles of $40 \mathrm{~s}$ at $94{ }^{\circ} \mathrm{C}, 40 \mathrm{~s}$ at $55^{\circ} \mathrm{C}, 1 \mathrm{~min}$ at $72{ }^{\circ} \mathrm{C}$, and terminating with a final hold of $4 \mathrm{~min}$ at $72^{\circ} \mathrm{C}$. All PCR amplicons were cleaned using AxyPrep DNA Gel Extraction Kit (Axygen Biotechnology, Hangzhou, China). All amplicons were sequenced from both sides using PCR primers. The PCR products were run on an ABI 3700 sequencer (Applied Biosystems, CA, USA).

The newly determined SSU rDNA and ITS sequences were aligned with other sequences from GenBank database. After the elimination of apparently erroneous sequences and ambiguously aligned regions, two sets of alignments were produced by using Clustal X (v1.8) (THompson et al. 1997) and MUSCLE (EDGAR 2004), and then modified manually by using MEGA7 (KumAr et al. 2016). For SSU and ITS analyses, 44 taxa with 1569 characters and 48 taxa with 519 characters were aligned, respectively. Chlamydomonas reinhardtii P.A. Dangeard was selected as outgroup. Phylogenies were estimated using maximum likelihood (ML) and Bayesian inference (BI) as implemented in RAxML (v7.2.6) (Stamatakis 2006) and MrBayes (v3.1.2) (HUELSENBECK \& RONQUIST 2001). The program jModelTest (v2.1.5) was used to explore the model of sequence evolution that best fits the data set by the Akaike information criterion (DARRIBA et al. 2012). The evolutionary models used in ML and $\mathrm{BI}$ analyses for SSU and ITS phylogenies were TIM2 $+\mathrm{I}+\mathrm{G}$ and $\mathrm{GTR}+\mathrm{I}+\mathrm{G}$, respectively. In ML analyses, nodal support was assessed using 1,000 nonparametric bootstrap replicates. All Bayesian Markov Chain Monte Carlo (MCMC) analyses were run with seven Markov chains (six heated chains, one cold) for 1,000,000 generations. Trees were sampled every 100 generations. We obtained posterior probability (PP) values for the branching patterns in $\mathrm{BI}$ trees as well as bootstrap (bootstrap support value, BP) values in ML trees.

Table 1. List of strains obtained from this work.

\begin{tabular}{|c|c|c|c|c|c|c|}
\hline $\begin{array}{c}\text { Strain } \\
\text { designation }\end{array}$ & Species & Locality & Coordinates & Collection data & $\begin{array}{c}\text { Accession } \\
\text { number } \\
\text { SSU }\end{array}$ & $\begin{array}{c}\text { Accession } \\
\text { number } \\
\text { ITS }\end{array}$ \\
\hline FACHB-2251 & $\begin{array}{l}\text { Planktosphaeria } \\
\text { hubeiensis }\end{array}$ & $\begin{array}{l}\text { Bailian River, Huanggang, } \\
\text { Hubei Province, China }\end{array}$ & $\begin{array}{l}30^{\circ} 35^{\prime} 53^{\prime \prime} \mathrm{N} \\
115^{\circ} 27^{\prime} 11^{\prime \prime} \mathrm{E}\end{array}$ & 10 May 2015 & MG712828 & MG712833 \\
\hline FACHB-2248 & Radiococcus sp. & $\begin{array}{l}\text { Hongsi Lake, Hanzhong, } \\
\text { Shaanxi Province, China }\end{array}$ & $\begin{array}{l}32^{\circ} 54^{\prime} 12^{\prime \prime} \mathrm{N} \\
106^{\circ} 52^{\prime} 45^{\prime \prime} \mathrm{E}\end{array}$ & 17 Aug. 2013 & MG712830 & MG712834 \\
\hline FACHB-2249 & Radiococcus sp. & $\begin{array}{c}\text { Shimen Reservoir, } \\
\text { Hanzhong, Shaanxi Prov- }\end{array}$ & $\begin{array}{l}33^{\circ} 12^{\prime} 31^{\prime \prime} \mathrm{N} \\
106^{\circ} 57^{\prime} 43^{\prime \prime} \mathrm{E}\end{array}$ & 17 Aug. 2013 & MG712832 & MG712829 \\
\hline FACHB-2250 & Radiococcus sp. & $\begin{array}{l}\text { ince, China } \\
\text { Pond in Wuhan Zoo, Wu- } \\
\text { han, Hubei Province, China }\end{array}$ & $\begin{array}{l}30^{\circ} 32^{\prime} 28^{\prime \prime} \mathrm{N} \\
114^{\circ} 14^{\prime} 27^{\prime \prime} \mathrm{E}\end{array}$ & 10 Jun. 2013 & MG712831 & MG712827 \\
\hline
\end{tabular}




\section{Results}

Planktosphaeria hubeiensis Q. Zhang, G.X. Liu et L.R. Song sp. nov. (Fig. 1A-E)

Description: Vegetative cells in colonies, green, planktonic. Cells spherical, multinucleate, $8-22 \mu \mathrm{m}$ in diameter. Chloroplasts numerous, discoid and parietal, with one to several pyrenoids. Chloroplasts usually with a pyrenoid in young cells, with several pyrenoids at maturity. Colonies spherical or irregularly shaped $(20-60 \mu \mathrm{m}$ in diameter), consisting of 8-16 (32) cells covered by a structureless gelatinous envelope. Usually many small colonies form loose aggregations, measuring $0.5-1 \mathrm{~mm}$ in diameter. Asexual reproduction by autosporulation, sexual reproduction not observed. 8-16 (32) autospores in the mother cell wall, released by the splitting of the mother cell wall. Sporangial cell wall gelatinized after enlargement and formation of Gloeocapsa-like colonies.

Holotype: Material of the authentic strain FACHB-2251 was permanently cryopreserved in Freshwater Algae Culture Collection at the Institute of Hydrobiology (FACHB-collection), Chinese Academy of Sciences, Wuhan, Hubei, China. Also available in FACHB-collection as a perpetually transferred culture, strain FACHB-2251, from which the holotype was derived. The holotype material was the source of SSU and ITS deposited as GenBank accession numbers MG712828 and MG712833, respectively.

Type locality: Bailian River, Huanggang, Hubei Province, PR China (30॰35'53"N, 115²7'11"E).

Etymology: The species epithet 'hubeiensis' is derived from the type locality Hubei Province.

The colonies of Radiococcus sp. strain FACHB-2248 (Fig. 1F-I) were spherical or irregularly shaped (12-50 $\mu \mathrm{m}$ in diameter), consisting of 4 (8) cells in a gelatinous envelope. Cells were spherical, 6-12 $\mu \mathrm{m}$ in diameter. The chloroplast was single, cup-shaped and parietal, with a pyrenoid (Fig. 1I). 4 autospores were arranged in tetrahedral shapes in the mother cell wall, released by the splitting of the mother cell wall, with cap-like wall remnants persisting thereafter (Fig. 1F-H). Sexual reproduction was not observed.

The colonies of Radiococcus sp. strain FACHB-2250

(Fig. 1J-L) were spherical or irregularly shaped (12-20 $\mu \mathrm{m}$ in diameter), consisting of (2) 4 (8) cells covered by a structureless gelatinous envelope. Cells were spherical, multinucleate, 4-9 $\mu \mathrm{m}$ in diameter. The chloroplast was single, cup-shaped and parietal, with 1-2 pyrenoids (Fig. $1 \mathrm{~L}-\mathrm{N})$. (2) 4 (8) autospores in the mother cell wall were released by the splitting of the mother cell wall. Sexual reproduction was not observed.

\section{Transmission electron microscopy}

Vegetative cells of Planktosphaeria hubeiensis were spherical with a thick and layered cell wall (0.2-0.4 $\mu \mathrm{m}$ in thickness) (Fig. 2A-C, E). Young, uninucleate cells possessed a rather large, more or less cup-shaped and parietal chloroplast containing a pyrenoid covered by starch grains (Fig. 2C). The parietal chloroplasts in adult cells were irregularly discoid with several pyrenoids covered by starch envelope, occupying most of the cell volume (Fig. 2A-B). Significantly, numerous starch grains were surrounded by thylakoids in mature cells (Fig. 2A-B). The pyrenoids were covered by 3-5 large cup-shaped starch grains (Fig. 2G-H). The multiple nuclei were dispersed in the center of the cell at maturity (Fig. 2A-B, D). Usually each nucleus was adjacent to a dictyosome (Fig. 2D). Several mitochondrions with tubular cristae were somewhat rod-like around the chloroplasts (Fig. 2F).

Vegetative cells of Radiococcus sp. strain FACHB-2248 were spherical with a thick, rough and layered cell wall (0.2-0.5 $\mu \mathrm{m}$ in thickness) (Fig. 2I-K). Autosporangial cell wall remnants could be observed under TEM (Fig. 2I-J). The single chloroplast was parietal cup-shaped with a pyrenoid covered by starch envelope, occupying most of the cell volume (Fig. 2I-J). Usually several starch grains were surrounded by thylakoids in mature cells (Fig. 2I-J). The conspicuous pyrenoid located at one side of the cell was covered by 3-4 large cup-shaped starch grains (Fig. 2I-J, L). One or several vacuoles were located at the other side of cell (Fig. 2I-J). The single nucleus was located in the cytoplasmic area enclosed by the chloroplast and usually associated with vacuole (Fig. 2J, M).

Vegetative cells of Radiococcus sp. strain FACHB-2250 were spherical with a rough and layered cell wall (0.05-0.2 $\mu \mathrm{m}$ in thickness) (Fig. 3A-C). The outermost layer of cell wall was furnished with toothlike projections (Fig. 3F). The parietal chloroplast was cup-shaped with one or two pyrenoids covered by starch envelope (Fig. 3A-C). Usually several starch grains were surrounded by thylakoids in mature cells (Fig. 3A-B). Young cells were uninucleate, and then they developed into multinucleate cells during maturation (Fig. 3A-C). The pyrenoid(s) with 3-5 cup-shaped starch grains was located at one side of cell, and the nucleus was located at the other side of cell (Fig. 3A-C, E). Several mitochondrions with tubular cristae were somewhat dumbbell-shaped around the chloroplast (Fig. 3D, H). The dictyosome was located between a pyrenoid and a nucleus (Fig. 3G).

\section{Sequence analyses}

The sequences of Radiococcus sp. strain FACHB-2248 and FACHB-2249 included two introns in SSU rDNA. The first intron (364 bp) was located at position 368 (corresponding to an Escherichia coli rRNA gene). The second intron (425 bp) was located at position 943, well known position for group I introns (corresponding to an E. coli rRNA gene) (CANNONE et al. 2002). The sequences of Planktosphaeria hubeiensis strain FACHB-2251 also included the second intron in SSU rDNA. After removal of intron insertions and ambiguous regions in 

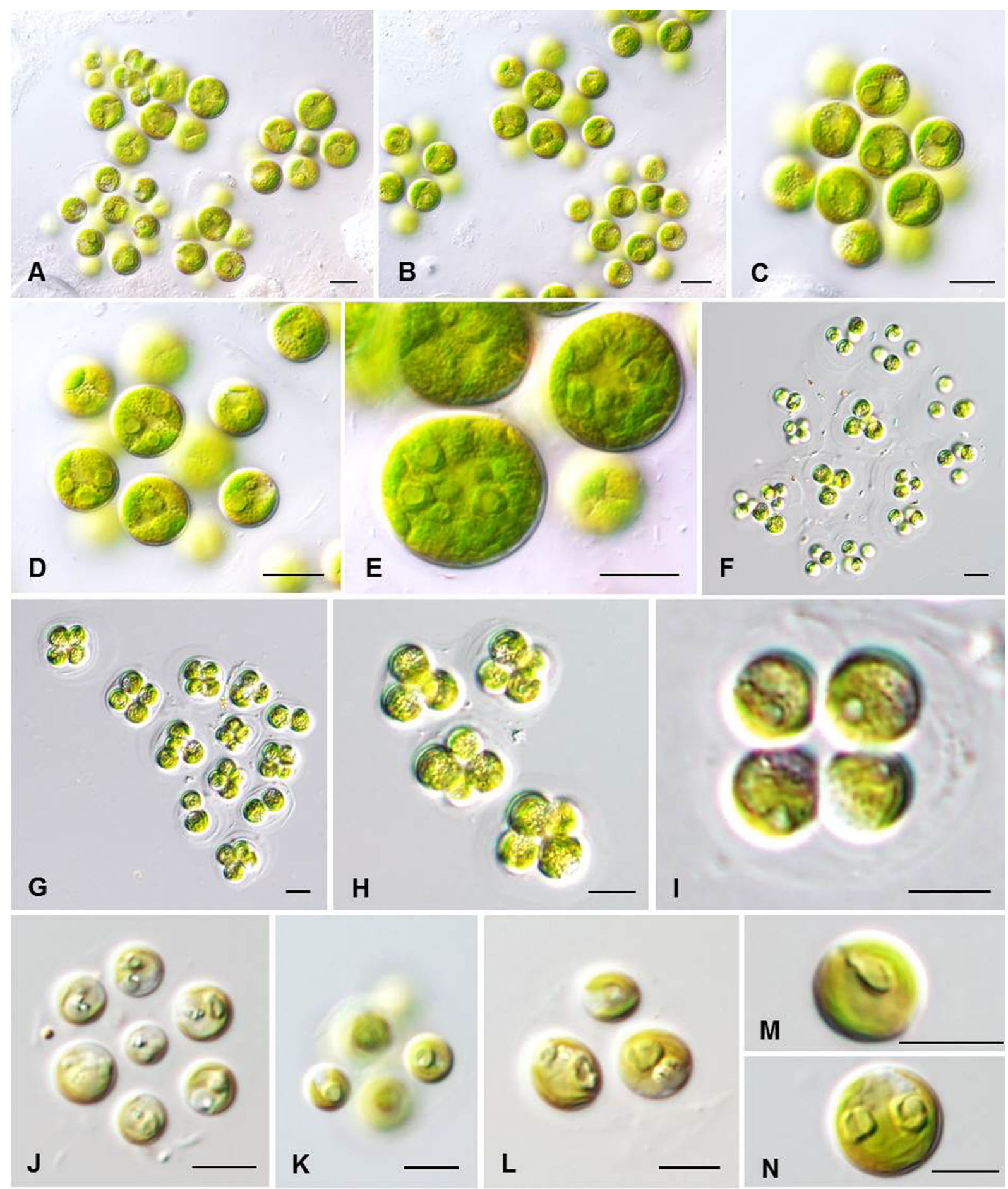

Fig. 1. Light micrographs of Planktosphaeria hubeiensis (A-E), Radiococcus sp. strain FACHB-2248 (F-I) and Radiococcus sp. strain FACHB-2250 (J-N): (A, B) spherical or irregularly shaped colonies with a structureless gelatinous envelope; (C) the colony with young cells; (D) the colony with maturing cells; (E) maturing cell, showing several parietal discoid chloroplasts with several pyrenoids; (F, H) spherical or irregularly shaped colonies with a structureless gelatinous envelope and cap-like remnants of sporangial cell wall; (H) 4 autospores arranged tetrahedrally; (I) cells showing parietal cup-shaped chloroplast with a pyrenoid; (J) spherical colonies; (K, L) 4 autospores arranged tetrahedrally; (M) cell showing parietal cup-shaped chloroplast with a pyrenoid; (N) cell showing parietal cup-shaped chloroplast with two pyrenoids. Scale bars $10 \mu \mathrm{m}(\mathrm{A}-\mathrm{I}) ; 5 \mu \mathrm{m}(\mathrm{J}-\mathrm{N})$.

some sequences, the alignment of SSU rDNA was used for phylogenetic analyses. The SSU and ITS sequences of strain FACHB-2248 were identical to those of strain FACHB-2249, respectively. The ITS sequence of $R$. polycoccus strain SAG 217-1b was also identical to
R. polycoccus strain SAG 217-1c. The SSU sequence divergence between $P$. hubeiensis strain FACHB-2251 and $P$. gelatinosa strain SAG $262-1 \mathrm{~b}$ was $2.3 \%$. R. polycoccus SSU sequence differences reached 3.3\% against Radiococcus sp. strain FACHB-2248 and FACHB-2249, 


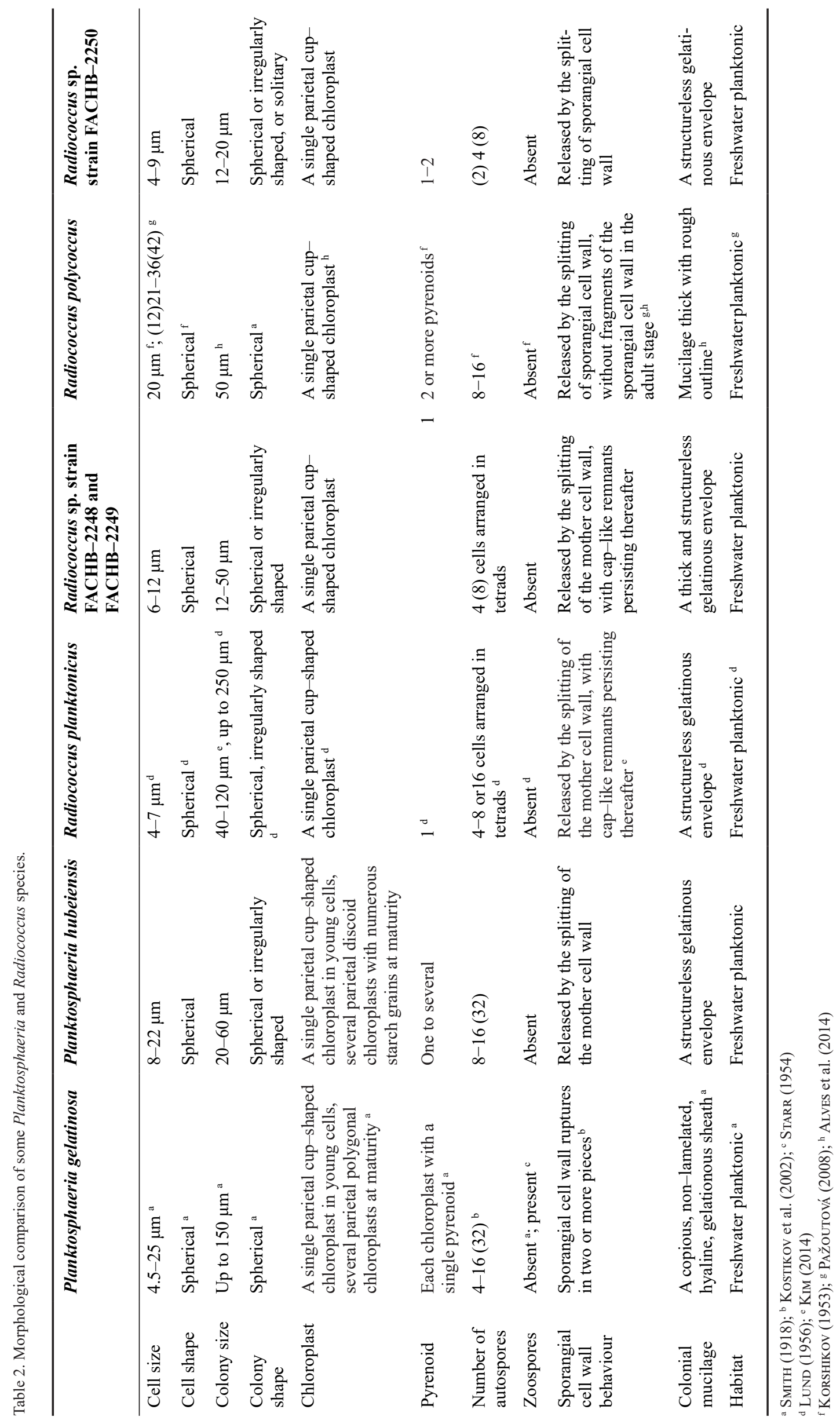



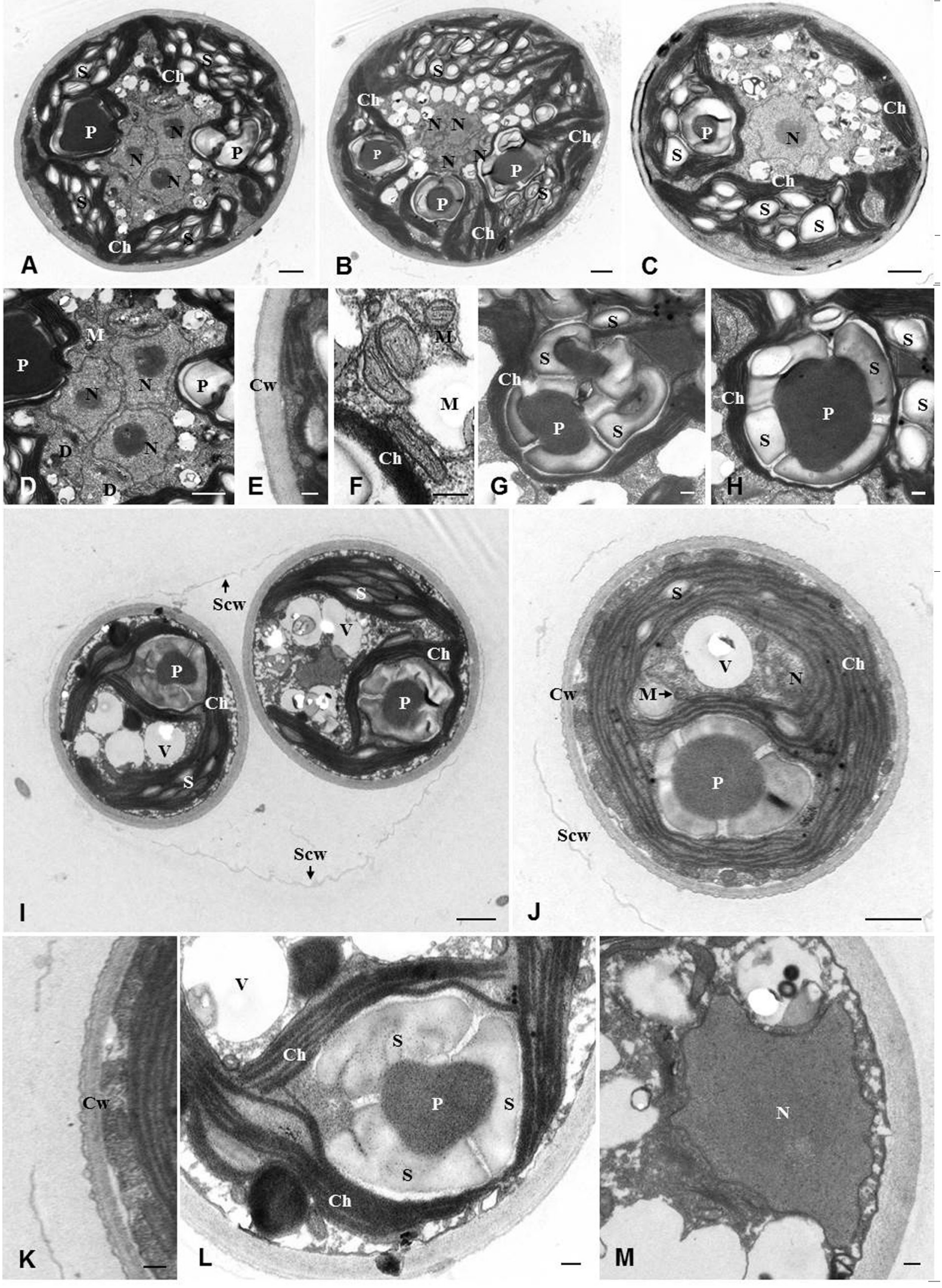

Fig. 2. Transmission electron micrographs of Planktosphaeria hubeiensis (A-H) and Radiococcus sp. strain FACHB-2248 (I-M): (A-B) section of a maturing cell, showing several parietal discoid chloroplasts with pyrenoids, several nuclei and numerous starch grains; (C) section of young, uninucleate cell, showing parietal cup-shaped chloroplast with a single pyrenoid; (D) part section of maturing cell, showing the dictyosome near nuclei; (E) detail of cell wall; (F) detail of several somewhat rod-like mitochondrions; $(\mathrm{G}-\mathrm{H})$ section showing the pyrenoids covered by $3-5$ large cup-shaped starch grains; (I-J) cell section showing parietal cup-shaped chloroplast with a pyrenoid, cap-like remnants of sporangial cell wall, starch grains and vacuoles; (K) detail of thick, rough and stratified cell wall; (L) detail of the conspicuous pyrenoid covered by 3-4 large cup-shaped starch grains; (K) detail of the nucleus. Scale bars $1 \mu \mathrm{m}(\mathrm{A}-\mathrm{D}, \mathrm{I}-\mathrm{J})$; $0.2 \mu \mathrm{m}(\mathrm{E}-\mathrm{H}, \mathrm{K}-\mathrm{M})$. Abbreviations: (D) dictyosome; (M) mitochondrion; (N) nucleus; (P) pyrenoid; (S) starch; (V) vacuole; (Ch) chloroplast; (Cw) cell wall; (Scw) sporangial cell wall. 

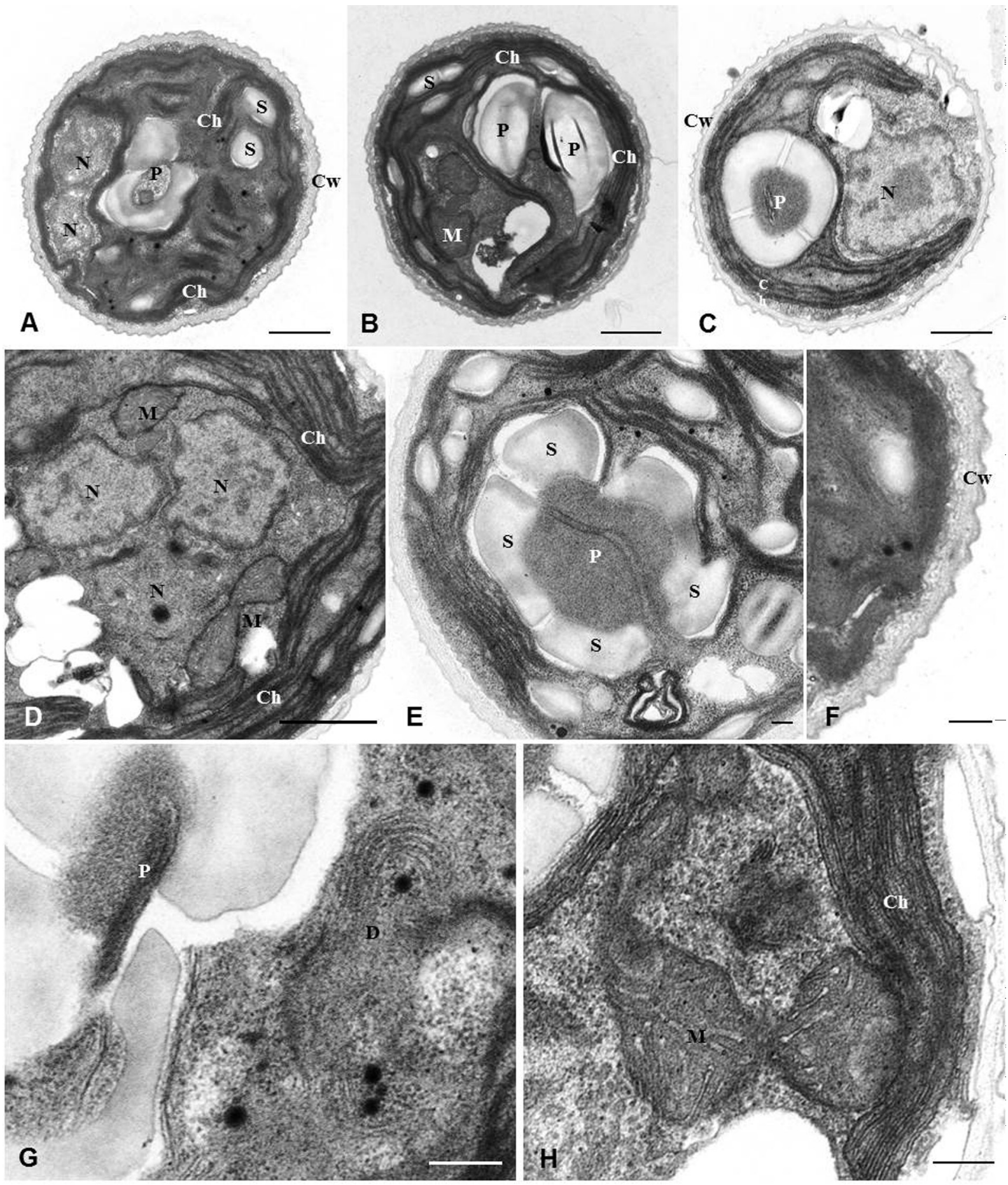

Fig. 3. Transmission electron micrographs of Radiococcus sp. strain FACHB-2250: (A-B) section of maturing cell, showing cup-shaped chloroplast with 1-2 pyrenoids, nuclei and starch grains; (C) section of young, uninucleate cell, showing parietal cup-shaped chloroplast with a pyrenoid; (D) detail of nuclei and dumbbell-shaped mitochondrions; (E) detail of the conspicuous pyrenoid covered by 4 large cup-shaped starch grains; (F) detail of rough and stratified cell wall furnished with tooth-like projections; (G) detail of dictyosome; (H) detail of dumbbell-shaped mitochondrion. Scale bars $1 \mu \mathrm{m}(\mathrm{A}-\mathrm{D}) ; 0.2 \mu \mathrm{m}(\mathrm{E}-\mathrm{H})$.

Abbreviations: (D) dictyosome; (M) mitochondrion; (N) nucleus; (P) pyrenoid; (S) starch; (Ch) chloroplast; (Cw) cell wall.

and $2.6 \%$ against Radiococcus sp. strain FACHB-2250.

\section{Molecular phylogeny}

The new sequences of SSU and ITS rRNA gene determined during this study and deposited in GenBank (Table 1). In SSU and ITS phylogenies, ML and Bayesian inference analyses yielded similar tree topologies. The ML trees with indication of Bayesian posterior probabilities were shown in Figs. 4 and 5. Our results showed that Radiococcaceae sensu lato, comprising the genera Radiococcus, Follicularia W.W. Miller, Planktosphaeria, Coenochloris Korshikov, Gloeocystis Nägeli, Coenocystis 
Korshikov and Neocystis Hindák, is a polyphyletic assemblage of coccoid mucilage forming chlorophytes in Sphaeropleales (Figs. 4, 5).

SSU phylogenies supported monophyletic Radiococcaceae sensu lato group I composed of sequences from Follicularia botryoides (W. Herndon) J. Komárek, F. texensis (H.W. Bischoff et Bold) Ettl et Komárek, Radiococcus polycoccus, $R$. planktonicus J.W.G. Lund and our Radiococcus strains with high support values $(\mathrm{BP}=0.98$ and $\mathrm{PP}=1.00)$ (Figs. 4). Two species of Radiococcaceae sensu lato group II Planktosphaeria gelatinosa and $P$. hubeiensis formed a highly supported clade (BP and PP $=1.00$ ) closely related to Radiococcaceae sensu lato group I (Figs. 4). Schizochlamys gelatinosa A. Braun appeared in basal position of group I and Planktosphaeria species. Radiococcaceae sensu lato group III comprising Coenochloris signiensis (Broady) Hindák, Gloeocystis polydermatica (Kützing) Hindák, Coenocystis inconstans Hanagata et Chihara, Neocystis brevis (W. Vischer) Kostikov et Hoffmann and N. mucosa Krienitz, Bock, Nozaki et Wolf was separated distinctively from groups I and II. Ooplanctella planoconvexa (Hindák) Pazoutová, Škaloud et Nemjová (formerly Coenochloris planoconvexa Hindák) was distantly related to Radiococcaceae sensu lato species in SSU phylogenies (Fig. 4). ITS phylogenies also supported that Radiococcaceae sensu lato fell into three groups, one of which group III was only remotely related to groups I and II (Fig. 5). S. gelatinosa was closely related to Planktosphaeria species with moderate supports (BP $<$ 0.50 and $\mathrm{PP}=0.93$ ) in ITS phylogenies (Fig. 5).

\section{Discussion}

The genera Planktosphaeria and Radiococcus are common freshwater radiococcacean taxa all over the world. SMiтh (1918) established the genus Planktosphaeria to accommodate the only planktonic species $P$. gelatinosa from a Wisconsin lake. The type species is characterized by spherical cells which, at maturity, contain several parietal, polygonal chloroplasts, each with a single pyrenoid (SMITH 1918). According to the original diagnosis P. gelatinosa was supposed to reproduce by autospores (SMITH 1918), but in a later publication he suggested the possibility of reproduction by autospores and zoospores (Sмітн 1933), however, Sмітн (1950) gave up the revision of reproduction by zoospores at last. Three zoosporine species $P$. botryoides W. Herndon, $P$. maxima H.W. Bischoff et Bold and P. texensis H.W. Bischoff et Bold were described subsequently (HERNDON 1958; BISCHOFF \& Bold 1963; KomáreK 1989). Follicularia, a genus rather similar to Planktosphaeria, was described by MiLLER (1924), with the single species F. paradoxalis W.W. Miller (Kouwets 1995). Starr (1954) doubted the existence of the genus Follicularia, and transferred the type species $F$. paradoxalis to Planktosphaeria. Unfortunately, authentic strains of the type species of
Planktosphaeria and Follicularia are not available. Nature and classification of the two genera had been a matter of confusion ever since the first description (KoUwETs 1995). According to the revision of LuKEšová (1993), zoosporine soil algae should be transferred to the genus Follicularia. Therefore, $P$. botryoides, $P$. maxima and $P$. texensis were placed to the genus Follicularia (LUKEŠOví 1993). A zoosporine strain identified as P. gelatinosa from soil samples was reported by STARR (1954). LuKEŠOvá (1993) transferred Starr's strain of P. gelatinosa to Follicularia, and renamed F. starrii LuKesová. According to the most recent taxonomical revision by KostIKov et al. (2002), the genus Planktosphaeria is described as spherical cells with several parietal chloroplasts and pyrenoids reproducing only by autospores. SCHMIDLE (1902) established the genus Radiococcus to accommodate the type species $R$. nimbatus (= Pleurococcus nimbatus De Wildeman). According to the original diagnosis (SCHMIDLE 1902), 4-celled coenobium is embedded within a ray-like structured mucilaginous envelope. FoтT (1974) doubted the existence of ray-like mucilage, and emphasized on tetrahedral arrangement. The genus Catenococcus Hindák in the family Hormotilaceae was firstly described by HiNDÁK (1977), and finally synonymized with Radiococcus (KostiKov et al. 2002). It is difficult to separate Radiococcus from Coenochloris (Kostikov 1953) and Eutetramorus Walton (BourRelly 1966). Eutetramorus lundii Bourrelly (BourRELly 1966) and Coenochloris planctonica (West et G.S. West) Hindák (HINDÁK 1984) were regarded as a synonym of R. planktonicus (Lund 1956). Sphaerocystis polycocca Korshikov was firstly described by KorshIKOv (1953), then renamed as Eutetramorus polycoccus (Korshikov) Komárek (KomÁREK 1979) and Coenochloris polycocca (Korshikov) Hindák (HINDÁK 1984), and finally identified as R. polycoccus (KostiKov et al. 2002). According to Kostikov et al. (2002), the genus Radiococcus is described as spherical cells with single parietal chloroplast and pyrenoid(s) reproducing only by (2-) 4-8 $(-16)$ autospores. The important divergences are the lack of sporangial cell wall remnants for Eutetramorus and elongate vegetative cell for Coenochloris (KostiKov et al. 2002).

The following morphological criteria are traditionally used for identifying Radiococcaceae species: cell size, shape and size of colony, type of chloroplast and pyrenoid, number of autospores, structure of colonial mucilage, and sporangial cell wall behaviour, ect. Vegetative cells of Planktosphaeria hubeiensis FACHB-2251 are very similar to the strains UTEX 124 and SAG 262-1b of $P$. gelatinosa based on morphological and ultrastructural observations (KouwETs 1995). Young uninucleate cells possess a rather large, more or less cup-shaped and parietal chloroplast containing a pyrenoid covered by starch grains. They subsequently develop multinucleate cells with numerous parietal chloroplasts and pyrenoids during maturation (KouwETs 1995). The starch grains surrounded by thylakoids in strain FACHB-2251 seem 
to be much numerous than in strains UTEX 124 and SAG 262-1b. In addition, strain FACHB-2251 can be discriminated from the $P$. gelatinos a strain SAG 262-1b by a characteristic intron insertion at position 943 , and SSU/ITS sequence differences. Therefore, strain FACHB-2251 should be treated as a new species. Our strains FACHB-2248, FACHB-2249 and FACHB-2250 belong to two separate Radiococcus species based on traditional morphological criteria. Radiococcus nimbatus (De Wildeman) Schmidle and $R$. wildemani (Schmidle) Korshikov differ in the presence of a radially striated mucilaginous envelope around the groups of cells (SCHMIDLE 1902). The cells of epiphytic $R$. nimbatus (8-15 $\mu \mathrm{m}$ in diameter) are larger than these of planktonic $R$. wildemani (3-5 $\mu \mathrm{m}$ in diameter). $R$. wildemani has a much thickened chloroplast and almost central pyrenoid (LuND 1956). R. pelagica Teiling lacks the radially striate mucilage, and is arranged frequently in botryoidal colonies (up to 13-18 $\mu \mathrm{m}$ in diameter) (LuND 1956). The cells of $R$. planktonicus are characteristically arranged in tetrads with cap-like remnants of mother cell wall (KIM 2014). In the arrangement and shape of the cells, type of chloroplast and pyrenoid, and sporangial cell wall behaviour, strain FACHB-2248 is morphologically similar to $R$. planktonicus (Table 2). Meanwhile, strain FACHB-2248 is identical with strain FACHB-2249 because they share the same morphological characteristics and DNA sequence in our analyses. However, despite lacking ultrastructural and molecular data of $R$. planktonicus, there are some significant morphological differences between the two strains and $R$. planktonicus. The former usually possesses larger cells and smaller colonies, whereas the latter possesses relatively smaller cells and larger colonies (Table 2). Beside the arrangement and shape of the cells, type of chloroplast and sporangial cell wall behavior, a conspicuous similarity between strain FACHB-2250 and $R$. polycoccus is that both of them possess more than one pyrenoid. However, the sizes of cell and colony of strain FACHB-2250 are significantly smaller than those of $R$. polycoccus (Table 2 ). ITS sequence of $R$. polycoccus strain SAG 217-1b from Sweden is identical to the strain SAG 217-1c from Cambridge University Botanic Garden, United Kingdom. SSU and ITS sequence divergences between strain FACHB-2250 and SAG 217-1b/217-1c are enough to distinguish the two species. The two Radiococcus species of strains FACHB-2248 (and FACHB-2249) and FACHB-2250 differ from their allied species based on morphological comparisons and genetic analyses, and may be treated as new species in the future. However, it is premature to describe any new species of Radiococcus now because our phylogentic analyses do not support the monophyly of the genus.

Our phylogenetic results indicated that Radiococcaceae sensu lato revised by KostiKov et al. (2002) was polyphyletic, and separated into three lineages. Radiococcaceae sensu lato group I, comprising species of Radiococcus and Follicularia, affiliated with Radiococcaceae sensu lato group II comprising Planktosphaeria species in our SSU and ITS phylogenies. According to the review of LUKEŠOví (1993) and KosTIKOV et al. (2002) base on morphological perspective, the genera Radiococcus, Planktosphaeria and Follicularia are closely related. WoLF et al. (2003) indicated an evolutionary relationship between Planktosphaeria, Radiococcus and Bracteacoccus Tereg, representing the sister group of a clade containing Scenedesmaceae, Hydrodictyaceae and Neochloridaceae. The family Schizochlamidaceae is erected to accommodate the genus Schizochlamys Braun et Kützing based on pyrenoid ultrastructure (e.g. stalked pyrenoid), zoospore flagellation and pseudocilia configuration (WUJEK \& GRETZ 1977). Based on phylogenetic evidence, however, Fučíkoví et al. (2014) recently constructed the family Schizochlamydaceae to accommodate Planktosphaeria and Schizochlamys, because a distinct phylogenetic distance separated the two genera from Radiococcaceae species. Meanwhile the genera Radiococcus and Follicularia were reserved in Radiococcaceae, but they did not give the re-definition of Radiococcaceae (Fučíkoví et al. 2014). The genus Radiococcus is paraphyletic with Follicularia in our phylogentic analyses. It is impossible to recognize the true "Radiococcus" lineage due to the lack of authentic strain of the type species $R$. nimbatus. Therefore, the genus Radiococcus should be revised based on a detailed examination of morphology and phylogeny. In our phylogenetic analyses, Radiococcaceae sensu lato group III, including Coenochloris signiensis, Gloeocystis polydermatica, Coenocystis inconstans, Neocystis brevis and N. mucosa, is distantly related to group I and II. In addition, as stated by PAžoutoví et al. (2010), the coccoid green alga Coenochloris planoconvexa is distantly related to Radiococcaceae sensu lato, and affiliate very closely with Oocystaceae species. Because C. pyrenoidosa, the type species of Coenochloris, lay outside Oocystaceae, PAžoutoví et al. (2010) proposed a new genus Ooplanctella Pazoutová, Škaloud et Nemjová, with the type species $O$. planoconvexa. Therefore, Radiococcus and Follicularia could be kept in Radiococcaceae, however, Coenochloris, Gloeocystis, Coenocystis and Neocystis should be removed from Radiococcaceae in the future.

\section{ACKNOWLEDGEMENTS}

This work was financially supported by China Agriculture Research System (CARS-50) and Biological Resources Service Network Initiative, Chinese Academy of Sciences. We are grateful to Zhenfei Xing and Yuan Xiao at R\&D Division of Public Technology and Service, Institute of Hydrobiology, Chinese Academy of Sciences (IHB, CAS) for their assistance in TEM.

\section{REFERENCES}

Alves, F. R. R.; Gama JR, W. A. \& de Nogueira, I. S. (2014): Planktonic Radiococcaceae Fott ex Komárek of the Tigres Lake system, Britânia, Goiás State, Brazil. 


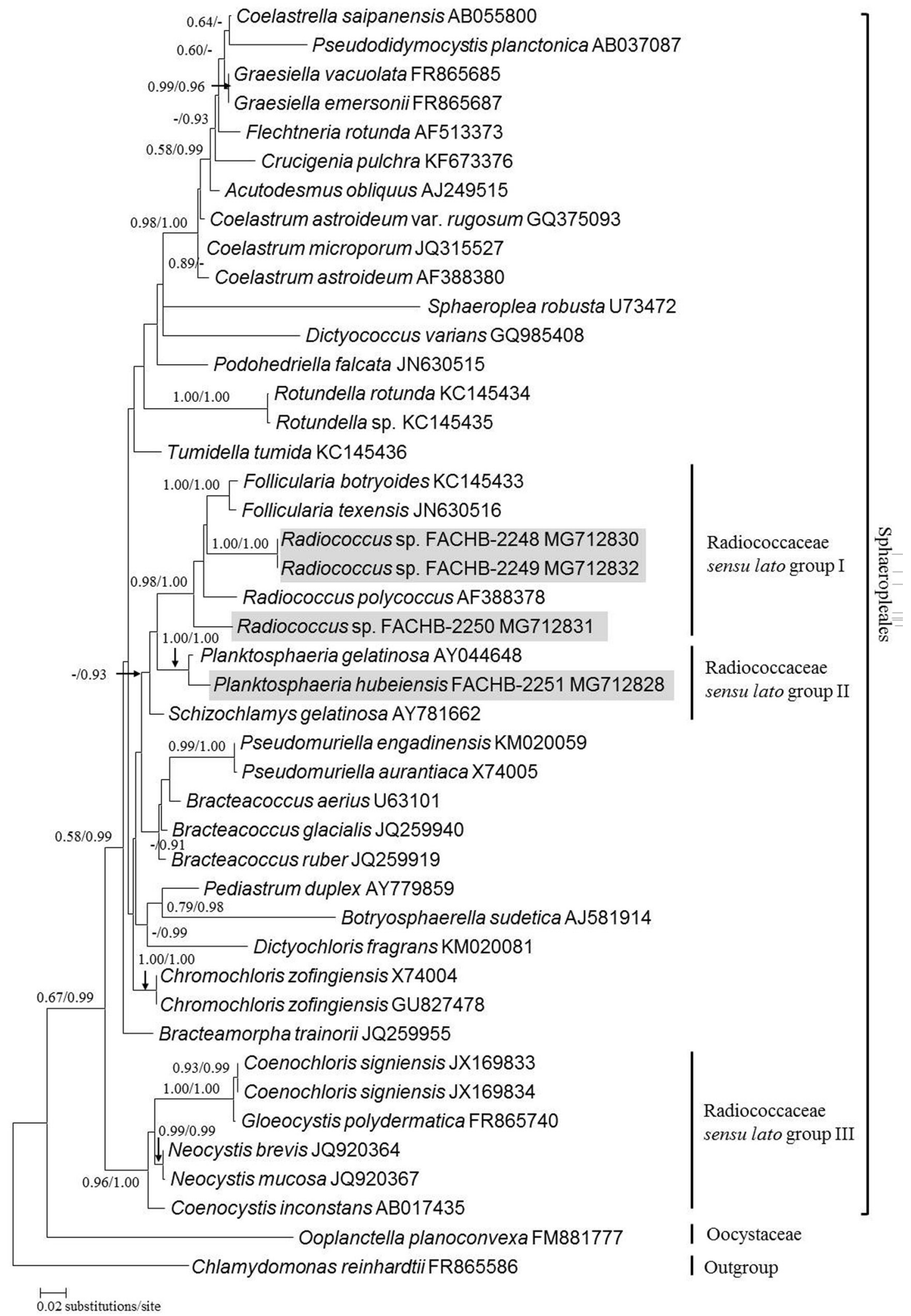

Fig. 4. Maximum likelihood phylogenetic tree constructed from small subunit (SSU) ribosomal DNA sequences. Numbers at nodes represent bootstrap support values (BP) / posterior probabilities (PP) from maximum likelihood and Bayesian inference, respectively. Only values $>0.50$ for BP and > 0.90 for PP are shown. The sequences obtained in our study are shaded grey. 


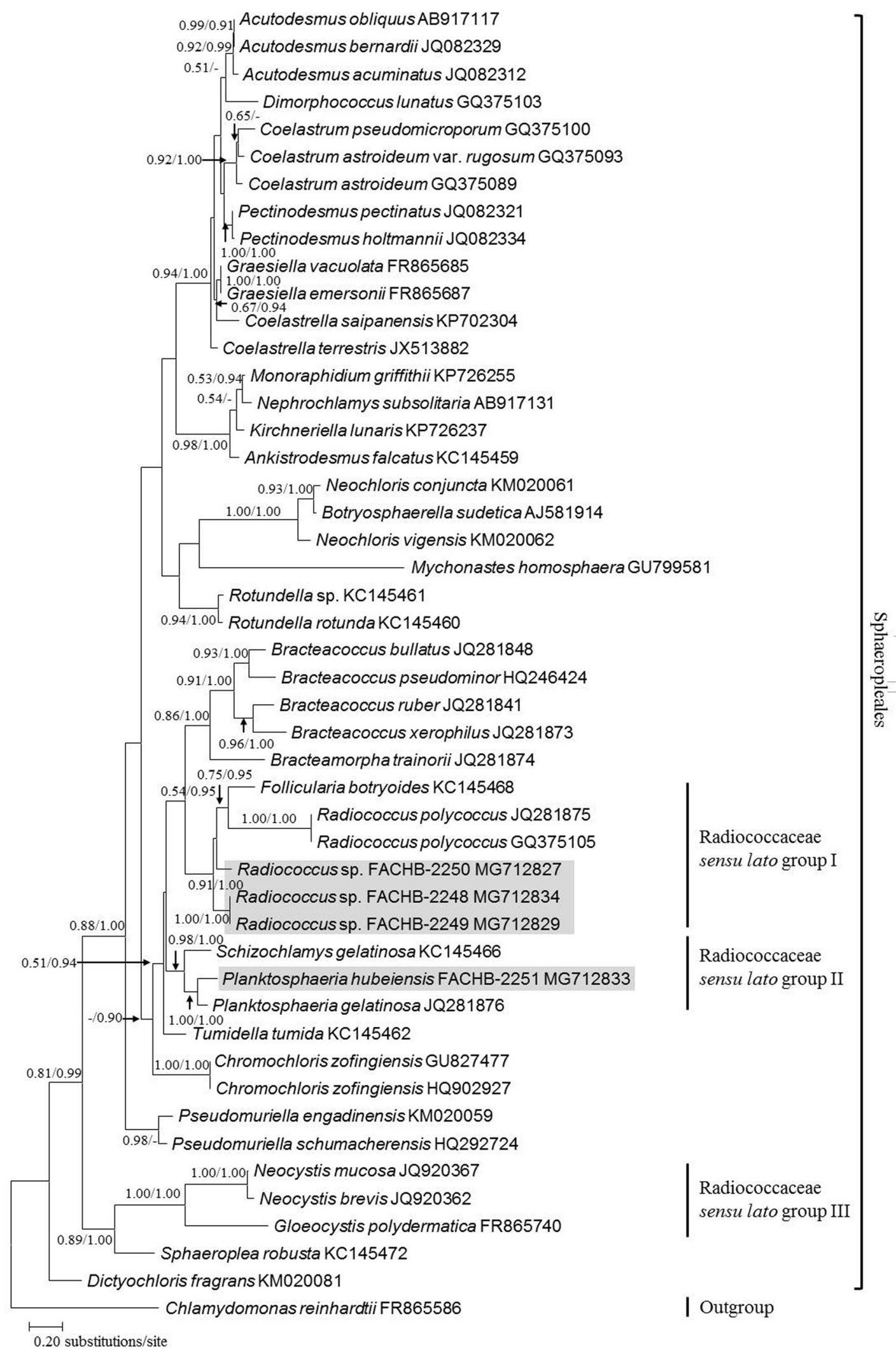

Fig. 5. Maximum likelihood phylogenetic tree constructed from internal transcribed spacer (ITS) sequences. Numbers at nodes represent bootstrap support values (BP) / posterior probabilities (PP) from maximum likelihood and Bayesian inference, respectively. Only values $>0.50$ for $\mathrm{BP}$ and $>0.90$ for PP are shown. The sequences obtained in our study are shaded grey. 
- Braz. J. Bot. 37: 519-530.

Bischoff, H. W. \& Bold, H. C. (1963): Phycological studies. IV. Some soil algae from enchanted rock and related algal species. - pp. 1-95, University of Texas Publication No. 6318, Austin, Texas.

Bourrelly, P. (1966): Les algues d'eau douce. Initiation à la Systèmatique. Les algues vertes. Editions N. - 511 pp., Boubèe, Paris.

BROADY, P. A. (1986): Ecology and taxonomy of the terrestrial algae of the Vestfold Hills. - In: Pickard, J. (ed.): Antarctic Oasis. - pp. 165-202, Academic Press, Sydney, Australia.

Cannone, J. J.; Subramanian, S.; Schnare, M. N.; Collett, J. R.; D’Souza, L. M.; Du, Y.; Feng, B.; Lin, N.; Madabusi, L. V.; Müller, K. M.; Pande, N.; Shang, Z.; Yu, N. \& Gutell, R. R. (2002): The Comparative RNA Web (CRW) Site: an online database of comparative sequence and structure information for ribosomal, intron, and other RNAs. - BMC Bioinformatics 3: 2-15.

Darriba, D.; Taboada, G. L.; DoAllo, R. \& Posada, D. (2012): jModelTest 2: more models, new heuristics and parallel computing. - Nature Methods 9: 772.

EDGAR, R. C. (2004): MUSCLE: a multiple sequence alignment method with reduced time and space complexity. - BMC Bioinformatics 5: 1-19.

Flechtner, V. R.; Johansen, J. R. \& Clark, W. H. (1998): Algal composition of microbiotic crusts from the central desert of Baja California, Mexico. - Great Basin Nat. 58: 295-311.

Fotт, B. (1959): Algenkunde. - 482 pp., Gustav Fischer Verlag, Jena.

FotT, B. (1974): Taxonomie der palmelloiden Chlorococcales (Familie Palmogloeaceae). - Preslia 46: 1-31.

Fučíkoví, K.; Lewis, P. O. \& Lewis, L. A. (2014): Putting incertae sedis taxa in their place: a proposal for ten new families and three new genera in Sphaeropleales (Chlorophyceae, Chlorophyta). - J. Phycol. 50: 14-25

HeRndon, W. (1958): Some new species of chlorococcacean algae. - Amer. J. Bot. 45: 308-323.

HindÁK, F. (1977): Studies on the chlorococcal algae (Chlorophyceae). I. - Biologicke Práce 23: 1-192.

Hindák, F. (1984): Studies on the Chlorococcal Algae (Chlorophyceae). III. - Biologicke Práce 30: 1-310.

HuelsenBeck, J. \& RonQuist, F. (2001): MRBAYES: bayesian inference of phylogenetic trees. - Bioinformatics 17: 754-755.

Katana, A.; Kwiatowski, J.; Spalik, K.; Zakryś, B.; SZalacha, E. \& Szymanska, H. (2001): Phylogenetic position of Koliella (Chlorophyta) as inferred from nuclear and chloroplast small subunit rDNA. - Journal of Phycology 37: 443-451.

KIM, Y. J. (2014): Floristic survey and five new records of fresh-water coccoid green algae (genus Coenochloris, Radiococcus, Schizochlamydella, and Thorakochloris). - J. Ecol. Environ. 37: 351-363

KomÁreK, J. (1979): Änderungen in der Taxonomie der Chlorokokkalgen. - Algological Studies 24: 239-263.

KomÁReK, J. (1989): Polynuclearity of vegetative cells in coccal green algae from the family Neochloridaceae. - Arch. Protistenkd. 137: 255-273.

KomÁReK, J. \& FotT, B. (1983): Chlorophyceae (Grünalgen) Ordnung: Das Phytoplankton des Süßwassers. - In: Huber-Pestalozzi, G. (ed.): Das Phytoplankton des Süsswassers (Die Binnengewässer) XVI. - pp. 1-445, Schweizerbart'sche Verlagsbuchhandlung, Stuttgart.
Korshikov, A. A. (1953): Viznachnik prisnovodnihk vodorostey Ukrainsykoi RSR [Vyp] V. Pidklas Protokokovi (Protococcineae). Bakuol'ni (Vacuolales) ta Protokokovi (Protococcales) [The Freshwater Algae of the Ukrainian SSR. V. Sub-Class Protococcineae. Vacuolales and Protococcales]. - pp. 1-439, Akad. NAUK URSR, Kyjev.

Kostikov, I.; Darienko, T.; Lukešoví, A. \& Hoffmann, L. (2002): Revision of the classification system of Radiococcaceae Fott ex Komárek (except the subfamily Dictyochlorelloideae) (Chlorophyta). - Algological Studies 104: 23-58.

Kouwets, F. A. C. (1995): Ultrastructural aspects of the cell cycle in Planktosphaeria gelatinosa (Chlorophyceae), with emphasis on the flagellar apparatus of the zoospore. - Arch. Protistenkd. 146: 37-48.

Krienitz, L. \& Bock, C. (2012): Present state of the systematics of planktonic coccoid green algae of inland waters. - Hydrobiologia 698: 295-326.

Krienitz, L.; Hegewald, E.; Hepperle, D. \& Wolf, M. (2003): The systematics of coccoid green algae: 18S rRNA gene sequence data versus morphology. - Biologia 58: 437-446.

Kumar, S.; Stecher, G. \& TAmura, K. (2016): MEGA7: molecular evolutionary genetics analysis version 7.0 for bigger datasets. - Molecular Biology and Evolution 33: $1870-1874$.

Lemmermann, E. (1915): Tetrasporales. - In: Pascher, A (ed.): Die Süsswasserflora Deutschlands, Österreichs und der Schweiz. Heft 5. - pp. 21-51, Gustav Fischer Verlag, Jena.

Lewis, L. A. \& McCourt, R. M. (2004): Green algae and the origin of land plants. - American Journal of Botany 91: $1535-1556$.

LuKešová, A. (1993): Revision of the genus Follicularia MILL. (Chlorophyceae). - Arch. Protistenkd. 143: 87-100.

LunD, J. W. G. (1956): On certain planktonic palmelloid green algae. - Journal of the Linnean Society of London, Botany 55: 593-613.

Luo, W.; Pflugmacher, S.; Pröschold, T.; Walz, N. \& KRIENITZ, L. (2006): Genotype versus phenotype variability in Chlorella and Micractinium (Chlorophyta, Trebouxiophyceae). - Protist 157: 315-333.

Miller, W. (1924): Follicularia, eine neue Chlorophyceengattung. Russkii Arkhiv Protistologii 3: 171-173.

Patova, E. N. \& Dorokhova, M. F. (2008): Green algae in tundra soils affected by coal mine pollutions. - Biologia 63: 831-835.

PAžoutoví, M. (2008): Phylogenetic diversity and generic concept in the family Radiococcaceae, Chlorophyta. - pp. 1-74, Diplomove prace, Univerzita Karlova v Praze, Praha.

Pažoutoví, M.; Škaloud, P. \& Nemuová, K. (2010): Phylogenetic position of Ooplanctella planoconvexa, gen. et comb. nova and Echinocoleum elegans (Oocystaceae, Trebouxiophyceae, Chlorophyta). - Fottea 10: 75-82.

Schmidle, W. (1902): Über die Gattung Radiococcus Schmidle n. gen. - Allgem. Bot. Zeitschr. 8: 41-42.

SмiтH, G. M. (1918): A second list of algae found in Wisconsin lakes. - Transactions of the Wisconsin Acadademy of Science, Arts and Letters 19: 614-654.

Smith, G. M. (1933): The fresh-water algae of the United States. - 716 pp., McGrew-Hill, New York.

Sмith, G. M. (1950): The fresh-water algae of the United States. 2nd Edition. - 719 pp., McGrew-Hill, New York.

Soylu, E. N. \& GöNüLOL, A. (2012): Morphological and 18S 
rRNA analysis of coccoid green algae isolated from lakes of Kizılırmak Delta. - Turkish Journal of Biology 36: 247-254.

SPURR, A. R. (1969): A low viscosity epoxy resin embedding medium for electron microscopy. - J. Ultrastruct. Res. 26: 31-43.

STARR, R. C. (1954): Reproduction by zoospores in Planktosphaeria gelatinosa G.M. SMITH. -Hydrobiologia 6: 392-397.

StAMATAKIS, A. (2006): RAxML-VI-HPC: maximum likelihood-based phylogenetic analyses with thousands of taxa and mixed models. - Bioinformatics 22: 2688-2690.

Stanier, R. Y.; Kunisawa, R. \& Mandel, M. (1971): Purification and properties of unicellular blue-green algae. Bacteriological Reviews 35: 171-205.

Thompson, J. D.; Gibson, T. J. \& Plewniak, F. (1997): The
Clustal X windows interface: flexible strategies for multiple sequence alignment aided by quality analysis tools. - Nucleic Acids Research 25: 4876-4882.

Wolf, M.; Hepperle, D. \& Krienitz, L. (2003): On the phylogeny of Radiococcus, Planktosphaeria and Schizochlamydella (Radiococcaceae, Chlorophyta). - Biologia 58: 759-765.

WujeK, D. E. \& Gretz, M. R. (1977): An ultrastructural study of the pyrenoid of Schizochlamys (Chlorophyceae: Tetrasporales). - Trans. Amer. Micros. Soc. 96: 398-402.

(C) Czech Phycological Society (2018)

Received January 2, 2018

Accepted May 30, 2018 